\title{
UPAYA MEMASYARAKATKAN ASTRONOMI MELALUI ASTRONOMY IN CAR FREE DAY (CFD) DI KOTA MALANG
}

\author{
A. Yasrina1, Y. Affriyenni ${ }^{2}$, J. Utomo ${ }^{3}$, C.I Yogihati ${ }^{4}$, A.S.F Narariya ${ }^{5}$, A. Fajrin ${ }^{6}$, A.S \\ Factirohmani $^{7}$ \\ 1,2,3,4,5,6,7 Jurusan Fisika FMIPA Universitas Negeri Malang \\ e-mail: atsnaita.yasrina.fmipa@um.ac.id
}

\begin{abstract}
Abstrak
Astronomi lahir dari kebutuhan masyarakat seperti di bidang pertanian, dan kelautan. Akan tetapi masyarakat sendiri belum banyak yang mengenal fenomena astronomi dan cenderung membangun mitos-mitos tentang fenomena tersebut. Upaya mengenalkan astronomi perlu dilakukan kepada masyarakat. Akademisi telah banyak mengenalkan astronomi akan tetapi masih sebatas di sekolah. Mengenalkan astronomi kepada masyarakat yang lebih luas dilakukan dengan memanfaatkan kegiatan Car Free Day (CFD) sebagai contoh di CFD di Kota Malang. Kegiatan yang dilakukan adalah mengedukasi masyarakat tentang fenomena astronomi, dan pengamatan matahari dengan teleskop dan kaca mata matahari. Masyarakat memberi respon melalui kuisioner dengan skala likert. Respon masyarakat sangat baik, dengan nilai rata-rata sebesar 3,53 . Sebanyak $95.83 \%$ responden menyatakan perlu selalu diadakan kegiatan ini kembali.
\end{abstract}

Kata kunci: Astronomi, car free day, respon masyarakat

\begin{abstract}
Astronomy was born from the needs of society, such as in agriculture and marine fields. Yet, many people are not familiar with astronomical phenomena, and they tend to build myths about these phenomena. Efforts to introduce astronomy need to be spread to the society. Academics have introduced astronomy, yet they mostly did in the school place. Adding astronomy to a broader community is done by taking moments of Car Free Day (CFD) activities, for instance, at CFD in Malang. The event carried out was to educate the society about astronomical phenomena and observation of the Sun with the telescope and sunglasses. The community gave responses through questionnaires on a Likert scale. The society response was very good, with an average value of 3.53. As many as $95.83 \%$ of respondents stated that it was necessary to hold this activity again.
\end{abstract}

Keywords: Astronomy, car free day, community response

\section{PENDAHULUAN}

Astronomi lahir dari kebutuhan masyarakat seperti kebutuhan akan kalender untuk mengatur waktu bertani dan kebutuhan menentukan arah serta navigasi bagi pelaut (Wiramihardja, 2010). Saat ini Astronomi masih membantu dalam memenuhi kebutuhan masyarakat baik dalam bidang pertanian, kelautan, mapun keantariksaan. Akan tetapi Astronomi tidak hanya sebatas untuk memenuhi kebutuhan tersebut. Astronomi modern tidak hanya sekedar mengamati fenomena langit akan tetapi juga mempelajari dinamika bendabenda langit sampai tentang nasib akhir dari sistem alam semesta ini.

Dinamika benda langit memberi dampak adanya fenomena benda langit seperti gerhana, konjungsi planet, hujan meteor, dan aktivitas Matahari. Fenomena Astronomi ini belumlah banyak diketahui masyarakat, sehingga mereka lebih cenderung membangun mitos-mitos tentang fenomena yang terjadi di langit. 
Sebagai contoh jika ada "bintang jatuh" maka akan ada orang meninggal atau terjadi bencana. Masyarakat bahkan menamakan meteor tersebut bintang jatuh yang sebenarnya bukanlah suatu bintang, dan tentu tidak ada kaitannya dengan keajadian akan ada orang meninggal. Oleh karena itu banyak upaya dilakukan oleh akademisi untuk mengenalkan astronomi di masyarakat. Beberapa upaya tersebut seperti pengambangan observatorium di beberapa tempat sebagai contoh Obeservatorium Astronomi di Lampung yang juga disetujui oleh masyarakat untuk dikembangkan menjadi kawasan lain seperti area pengembangan ekonomi, perlindungan budaya nasional, dan konversi alam (Putri A.N.I dkk, 2019). Observatorium juga berfungsi memberikan informasi tentang arti penting astronomi, fenomena benda langit, sebagai tempat pelatihan, dan pengkajian astronomi (Qorib M., 2019). Upaya lain adalah mengembangkan pembelajaran astronomi dengan webcam melalui pengembangan sistem akuisisi berbasis teknologi murah, (teleskop, Spica, web camera, dan laptop) dan diadakan pelatihan untuk guru-guru (Ayu R.P, dkk, 2013). Pelatihan untuk guruguru dilakukan untuk mengajarkan astronomi, atau IPBA meningkatkan ketrampilan, dan dapat melaksanakan praktikum mengobservasi objek langit malam. Pelatihan seperti ini dapat meningkatan penguasaan materi IPBA dari kategori kurang menjadi baik (Pujani N.M,dkk 2013). Pengenalan Astronomi kepada guru juga dilakukan dengan pelatihan pembuatan alat peraga IPBA. Hasil yang telah diperoleh para guru mudah mempersiapkan dan menggunakan karena alat dan bahan mudah didapatkan dari lingkungan sekitar (Pujani N.M, 2018). Upaya pengenalan astronomi juga dengan pembinaan kepada guru-guru untuk menyiapkan siswanya mengikuti olimpiade Astronomi. Pembinaan ini menghasilkan peningkatan dalam penguasaan materi astronomi dengan dibuktikannya guru mampu menyelesaikan soal olimpiade astronomi SMP (Pujani, N.M, 2017).

Di lain sisi Universitas Negeri Malang (UM) mempunyai visi sebagaimana tertuang dalam Statuta UM tahun 2012 yaitu "Menjadi perguruan tinggi unggul dan menjadi rujukan dalam penyelenggaraan tridharma perguruan tinggi". Sementara itu visi Jurusan Fisika adalah"menjadi jurusan unggul dan menjadi rujukan dalam penyelenggaraan tridharma perguruan tinggi bidang fisika dan pembelajarannya". Visi UM, FMIPA, dan Jurusan Fisika menekankan kata "unggul dan menjadi rujukan". Keunggulan Jurusan Fisika adanya Kelompok Bidang Kajian (KBK) salah satunya Astronomi. KBK yang telah ditetapkan melalui Surat Keputusan Dekan FMIPA UM Nomor 17.3.23/UN32.3/KP/2015. Oleh karena itu sesuai dengan makna visi dan misi UM yaitu membuka akses seluas-luasnya sebagai tempat dan rujukan belajar bagi semua, maka perlu diadakan pembelajaran Astronomi kepada masyarakat atau memasyarakatkan atsronomi.

Program memasyrakatkan astronomi ini dapat dilakukan dimana saja. Akan tetapi dengan memanfaatkan salah satu kegiatan Car Free Day (CFD) yang dilakukan pemerintah kota Malang setiap hari Minggu di sepanjang Jalan Idjen Malang, membuka peluang besar untuk lebih mudah bertemu dengan masyarakat secara langsung dengan jumlah yang lebih banyak, sehingga memasyarakatkan astronomi ini harapannya akan lebih efektif dan efesien. Kegiatan ini dikemas dengan pengamatan Matahari menggunakan teleskop dan kaca mata Matahari, dan memberi penjelasan singkat tentang fenomena-fenomena astronomi kepada masyarakat.

Tujuan dari pengabdian masyarakat ini adalah mengenalkan Astronomi kepada masyarakat dengan mengedukasi masyarakat tentang fenomena Astrononomi terutama yang dekat dengan keseharian. Selain itu juga mengedukasikan alat yang digunakan dalam pengamatan objek Astronomi. Alat yang digunakan dalam pengamatan objek Astronomi ini adalah teleskop dan kaca mata Matahari, sehigga masyarakat mengenal dan dapat menggunakan teleksop untuk mengamati Matahari.

\section{METODE}

Metode pengabdian masyrakat dalam kegiatan Astronomy in Car Free Day ini 
adalah pendidikan masyrakat berupa penyuluhan atau penyampaian materi. Tujuan dari penyuluhan dan penyampaian materi dalam kegiatan ini adalah untuk meningkatkan pemahaman masyarakat tentang Astronomi. Materi edukasi yang diberikan ke masyarakat adalah bagian dan cara penggunaan teleksop dan kaca mata Matahari untuk mengamati Matahari, anatomi Matahari, dan fenomena-fenomena Astronomi. Sementara untuk mengetahui ketercapaian tujuan ini maka dilakukan uji respon kepada masyarakat.

Kegiatan pengabdian kepada masyarakat ini terdiri dari tiga kegiatan utama, yang pertama adalah persiapan baik alat maupun media, yang kedua adalah pelaksaan pengabdian di Car Free Day (CFD), dan yang ketiga adalah menganalisis hasil respon masyarakat terkait kegiatan ini. Secara terperinci untuk kegiatan pertama diuraikan sebagai berikut;

(1) menyiapkan brosur untuk masyarakat yang berisi tentang Matahari,

(2) menyiapkan peralatan dan bahan yaitu teleskop, filter Matahari, kaca mata Matahari,

(3) menyiapkan kuisioner bagi masyarakat. Sementara untuk kegiatan kedua, dilakukan dengan langkah sebagai berikut;

(1) mengeset peralatan di lokasi Car Free Day (CFD)

(2) memberikan paket pengabdian kepada masyarakat yang berisi pamfleat, lembar kuisioner, dan bolpoin,

(3) mengedukasi masyarakat tentang fenomena Astronomi khususnya tentang Matahari

(4) mengedukasi masyarakat tentang penggunaan kaca matahari,

(5) mengedukasi masyarakat tentang bagian-bagian teleskop dan penggunaannya

(6) mengajak masyarakat mengamati Matahari dengan kaca mata Matahari dan teleskop.

(7) menyampaiakan materi kepada masyarakat tentang fenomena astronomi dan berdiskusi kepada masyarakat di Car Free Day (CFD)

(8) mengajak myarakat melihat Matahari melalui teleskop dan kaca mata Matahari.
Kegiatan ketiga yaitu menganalisis hasil respon masyarakat. Instrumen pengumpulan data yang digunakan adalah form respon. Form respon ini digunakan untuk mengetahui respon pengguna terhadap brosur dan kegiatan Astronomy in $C F D$ ini. Instrumen untuk masyarakat berupa lembar angket respon menggunakan skala likert. Data yang diperoleh dari angket respon masyarakat selanjutnya dianalisis.

(1) Jawaban dikategorikan ke dalam pilihan: (a) Sangat baik, Baik, Cukup baik, dan Tidak baik, (b) Sangat bermanfaat, bermanfaat, Cukup bermanfaat, Tidak bermanfaat, (c) Sangat penting, Penting, Cukup penting, Tidak penting, (d) Sangat menarik, Menarik, Cukup menarik, Tidak menarik, (e) Sangat mudah, Mudah, Cukup mudah, Tidak mudah, (f) Melayani dengan sangat baik, Melayani dengan baik, Melayani dengan cukup baik, Tidak melayani dengan baik, (g) Sangat perlu, Perlu, Cukup perlu, Tidak perlu

(2) Mengubah kategori penilaian menjadi skor dengan ketentuan seperti pada Tabel (1) (Widoyoko, Putro S.E, 2013)

(3) Skor rata-rata dari hasil respon dihitung dengan menggunakan persamaan (1) yaitu

$$
\bar{X}=\sum X / n N,
$$

dengan $\bar{X}$ adalah skor rata-rata respon, $\sum X$ adalah jumlah skor respon, $n$ adalah jumlah butir pernyataan, dan $N$ adalah jumlah responden.

(4) Menetukan jarak interval (I) untuk menyusun klasifikasi dihitung dengan menggunakan persamaan (2)

$$
\begin{aligned}
i & =\frac{\text { skala tertinggi-skala terendah }}{\text { umlah skala }} \\
& =(4-1) / 4=0,75 .
\end{aligned}
$$

(5) Skor rata-rata hasil respon diubah menjadi nilai kualitatif dengan mengacu pada klasifikasi penilaian seperti pada Tabel (2) (Widoyoko, Putro S.E, 2013). 
Tabel 1. Ketentuan Pengubahan Skor Untuk Respon

\section{Nilai Kualitatif}

Nilai

Kuantitatif

Sangat baik, Sangat bermanfaat, Sangat penting Sangat menarik, Sangat mudah,

Melayani dengan sangat baik, Sangat perlu

Bermanfaat, penting, menarik, mudah, melayani dengan baik, perlu

Cukup bermanfaat, cukup penting, cukup menarik, melayani dengan cukup baik, cukup perlu

Tidak bermanfaat, tidak penting, tidak menarik, melayani dengan tidak baik, tidak perlu
4

3

2

1

Tabel 2 Klasifikasi Respon

\begin{tabular}{|c|c|c|}
\hline $\begin{array}{l}\text { Rentang Skor Rata- } \\
\text { Rata }\end{array}$ & Pilihan Jawaban & $\begin{array}{l}\text { Kategori } \\
\text { Jawaban }\end{array}$ \\
\hline $3,25<\bar{X} \leq 4,00$ & $\begin{array}{l}\text { Sangat baik, Sangat bermanfaat, Sangat penting } \\
\text { Sangat menarik, Sangat mudah, Melayani dengan } \\
\text { sangat baik, Sangat perlu }\end{array}$ & A \\
\hline $2,50<\bar{X} \leq 3,25$ & $\begin{array}{l}\text { Bermanfaat, penting, menarik, mudah, melayani } \\
\text { dengan baik, perlu }\end{array}$ & B \\
\hline $1,75<\bar{X} \leq 2,50$ & $\begin{array}{l}\text { Cukup bermanfaat, cukup penting, cukup menarik, } \\
\text { melayani dengan cukup baik, cukup perlu }\end{array}$ & C \\
\hline $1,00 \leq \bar{X} \leq 1,75$ & $\begin{array}{l}\text { Tidak bermanfaat, tidak penting, tidak menarik, } \\
\text { melayani dengan tidak baik, tidak perlu }\end{array}$ & D \\
\hline
\end{tabular}

\section{HASIL DAN PEMBAHASAN}

Kegiatan Astronomy in CFD dilakukan hari Minggu, 18 Agustus 2019. Rincian kegiatan yang telah dilakukan adalah persiapan, pelaksaan, dan analisis respon masyarakat. Tahap persiapan dengan penyusun kuisioner dan brosur materi yang akan disampaikan ke masyarakat dengan materi "mengenal Matahari" seperti yang ditunjukkan Gambar 1. Peralatan lain yang dipersiapkan adalah teleskop yang diberi filter Matahari, dan kaca mata Matahari.

Tahap pelaksanaan dimulai dengan mengeset teleskop di lokasi pengabdian. Pengabdian ini dilaksanakan bekerjasama dengan komunitas Astronomi KAPELA (Komunitaas Pengamat Langit) dan MAC (Malang Astronomy Club). Pengabdian dilakukan dengan mengedukasi masyarakat tentang fenomena Astronomi dan masyarakat diberikan paket pengabdian seperti yang ditunjukkan Gambar (2). Masyarakat kemudian diedukasi untuk dapat menggunakan teleskop dan kaca mata Matahari seperti yang ditunjukkan Gambar (3). Setelah masyarakat diedukasi baik dengan penyampaian materi, penggunaan teleksop, dan kaca mata Matahari, maka masyarakat diminta untuk mengisi kuisioner. Kuisioner ini berguna mengetahui respon masyarakat terkait brosur dan pelaksanaan pengabdian ini.

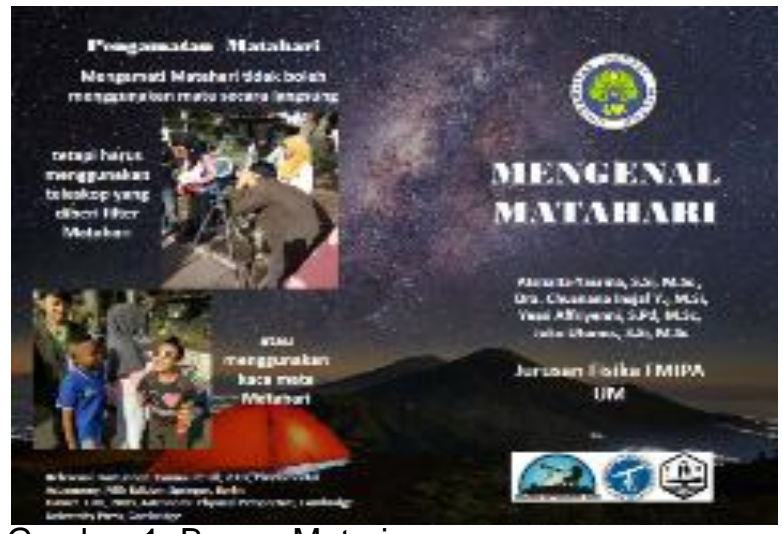

Gambar 1. Brosur Materi

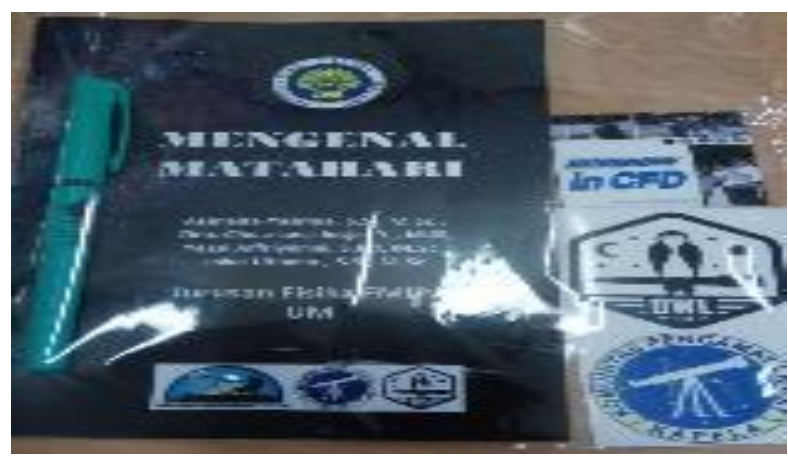

Gambar 2 Paket pengabdian yang terdiri dari brosur, kuisioner, bolpoint, dan souvenir 
Hasil analisis terkait respon masyarakat yang mengikuti pengabdian ini lebih banyak dari data repson yang diperoleh. Kuisoner diberikan kepada 72 responden. Dalam kuisioner tersebut terdiri dari satu data pribadi responden yaitu profesi, 7 pertanyaan terkait brosur dan jalannya pengabdian dengan pilihan jawaban terdiri dari 4 kategori, serta 1 pertanyaan dengan 2 kategori jawaban ya dan tidak. Tujuh pertanyaan dengan pilihan jawaban terdiri dari 4 kategori seperti pada Tabel (1). Profesi respon terdiri dari 53,30 $\%$ mahasiswa, 33,30 \%, 5,33 \% lainnya, dan $5,30 \%$ pelajar. $5,33 \%$ lainnya ini adalah seperti ibu rumah tangga. Sementara untuk hasil 7 pertanyaan yang lain seperti ditunjukan Tabel (3).Pertanyaan "Apakah kegiatan Astronomy in CFD UM perlu selalu diadakan?" sebanyak 95.83\% menyatakan perlu selalu diadakan, dan $4.16 \%$ tidak perlu diadakan. Berkaitan tujuan edukasi masyarakat dalam penggunaan teleksop dan kaca mata Matahari, sesuai hasil respon pada Tabel (3), responden manyatakan sangat baik dengan skor ratarata 3,51. Oleh karena itu, berdasarkan Tabel (3) pengabdian dalam bentuk upaya memasyarakatkan astronomi melalui
Astronomy in Car Free Day (CFD) Malang memperoleh skor rata-rata 3,53. Berdasarkan Tabel (2) maka pengabdian ini bagi masyarakat dinyatakan sangat baik. Oleh karena itu tujuan dari pengabdian ini bisa dinyatakan tercapai.

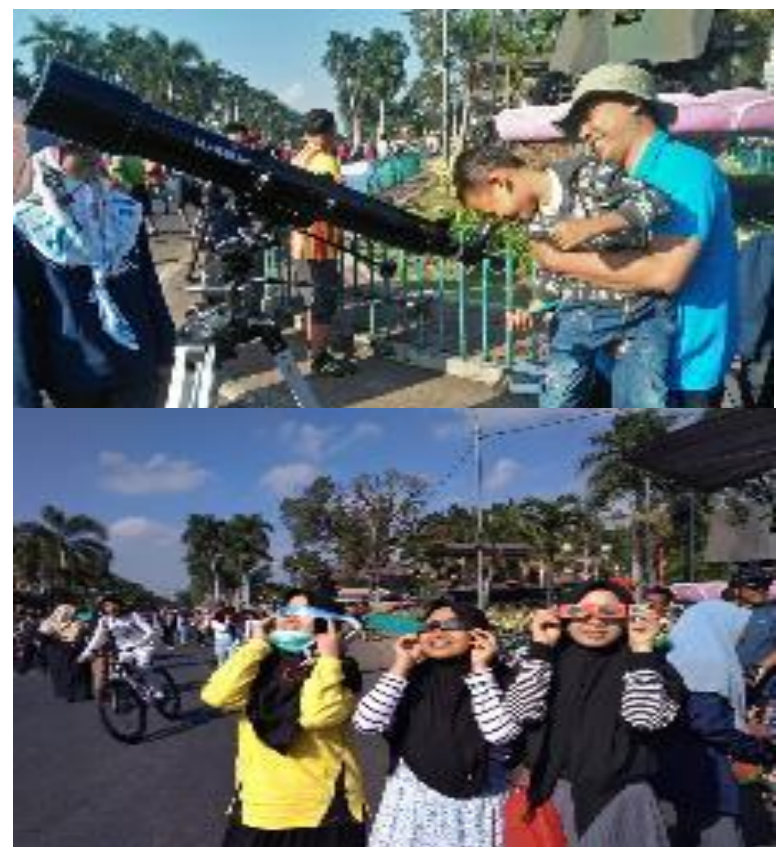

Gambar 3 Mengedukasi masyarakat dapat menggunakan teleskop dan kaca mata Matahari

Tabel 3. Respon Masyarakat

\begin{tabular}{|c|c|c|c|c|c|c|}
\hline \multirow[t]{2}{*}{ No } & \multirow[t]{2}{*}{ Pertanyaan } & \multicolumn{4}{|c|}{$\begin{array}{l}\text { Kategori } \\
\text { Jawaban }\end{array}$} & \multirow[t]{2}{*}{ Skor rata-rata } \\
\hline & & A & B & C & D & \\
\hline 1 & $\begin{array}{l}\text { Bagaimana pendapat Anda tentang kegiatan Astronomy } \\
\text { in CFD UM ini? }\end{array}$ & 47 & 21 & 2 & 0 & 3.54 \\
\hline 2 & $\begin{array}{l}\text { Seberapa pentingkah kegiatan Astronomy in CFD UM } \\
\text { perlu diadakan untuk masyarakat? }\end{array}$ & 31 & 36 & 6 & 0 & 3.39 \\
\hline 3 & $\begin{array}{l}\text { Bagaiamana pendapat Anda tetang kemanfaatan dari } \\
\text { kegiatan Astronomy in CFD UM ini? }\end{array}$ & 45 & 28 & 1 & 0 & 3.69 \\
\hline 4 & $\begin{array}{l}\text { Bagaimana pendapat Anda tentang brosur yang berisi } \\
\text { informasi tentang astronomi? }\end{array}$ & 36 & 32 & 5 & 0 & 3.47 \\
\hline 5 & $\begin{array}{l}\text { Bagaimana pendapat Anda dalam menggunakan } \\
\text { teleskop dan kaca mata Matahari dalam pengamatan } \\
\text { Matahari? }\end{array}$ & 44 & 22 & 5 & 1 & 3.51 \\
\hline 6 & $\begin{array}{l}\text { Bagaimana pendapat Anda tentang kami yang melayani } \\
\text { dalam kegiatan Astronomy in CFD UM? }\end{array}$ & 51 & 19 & 4 & 0 & 3.74 \\
\hline 7 & $\begin{array}{l}\text { Bagaimana pendapat Anda tentang kami yang melayani } \\
\text { dalam kegiatan Astronomy in CFD UM? }\end{array}$ & 29 & 36 & 9 & 0 & 3.36 \\
\hline & Skor rata-rata total & & & & & 3.53 \\
\hline
\end{tabular}


KESIMPULAN

Tujuan dari pengabdian ini adalah
mengenalkan
Astronomi kepada masyarakat dengan mengedukasi masyarakat tentang fenomena Astrononomi terutama yang dekat dengan keseharian yaitu mengenal Matahari. Selain itu mengenalkan penggunaan teleksop dan kaca Matahari kepada masyarakat luas dengan menfaatkan adanya Car Free Day di kota Malang. Masyarakat yang mau untuk menggunakan kaca mata Matahari dan teleksop cukup banyak dengan beragam profesi. Berkaitan tujuan edukasi masyarakat dalam penggunaan teleksop dan kaca mata Matahari, responden manyatakan sangat baik dengan skor ratarata 3,51. Respon masyarakat memiliki nilai rata-rata 3,53 atau menilai sangat baik kegiatan memasyarakatkan Astronomi melalui kegiatan Astronomy in Car Free Day (CFD). Oleh karena itu tujuan dari pengabdian ini bisa dinyatakan tercapai. Selain itu sebanyak sebanyak 95.83\% responden menyatakan pengabdian ini, perlu selalu diadakan.

\section{DAFTAR PUSTAKA}

Ayu, R.P. Priyatikanto, Soegiartini, E. Malasan, H.I Arifayanto, M.I. 2013. Pembelajaran Menggunakan Astronomi Conference Paper
Qorib, M. Zailani, Radiman, Amrizal, Rakhmadi, A. J.

Pujani, N.M, Rapi, N.K. 2012. Pelatihan Praktikum Ipba Bagi Guru Smp/Sma Di Kota Singaraja Menuju Olimpiade Astronomi. Jurnal Widia Laksana. $1: 2$

Pujani, N.M. 2018. Pelatihan Pembuatan Alat Peraga Ilmu Pengetahuan Bumi Antariksa bagi Kelompok Guru SMP dan SMA Lab. Undiksha Singaraja. International Journal of Community Service Learning. 2:1

Pujani, N.M. 2017. Pembekalan Materi Astronomi Bagi Guru-Guru IPA SMP di Kota Amlapura. Prosiding. SENADIMAS. 456-460

Putri, A.N.I IImi, W.Z. Vatikawa, A. Pratiwi, N. 2019. Kajian Pengelolaan dan Pengembangan Kawasan Observatorium Astronomi Lampung (OAL): Bagian 3. Journal of Multidisciplinary Academic. 3:2

Widoyoko, S. Eko Putro. 2013. Teknik Penyusunan Istrumen Penelitian. Yogyakarta: Pustaka Pelajar.

Wiramihardja, S. 2010. Astronomi Indonesia Menapak Ke Depan Dan Kontribusinya Pada Sebuah World Class University, Majelis Guru Besar Institut Teknologi Bandung, Bandung 